\title{
Curcumin induces human HT-29 colon adenocarcinoma cell apoptosis by activating p53 and regulating apoptosis-related protein expression
}

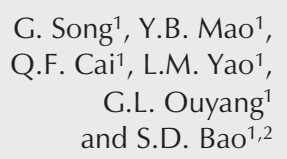

\author{
${ }^{1}$ The Key Laboratory, Ministry of Education for Cell Biology and \\ Tumor Cell Engineering, Xiamen University, Xiamen, China \\ 2Department of Pharmacology and Cancer Biology, \\ Duke University Medical Center, Durham, NC, USA
}

\section{Correspondence \\ G.L. Ouyang \\ The Key Laboratory \\ Ministry of Education for Cell \\ Biology and Tumor Cell Engineering \\ Xiamen University \\ 422 South Siming Road \\ Xiamen 361005 \\ China \\ Fax: +886-592-218-6091 \\ E-mail: glouyang321@hotmail.com \\ Research supported by the National Natural Science Foundation of China (Nos. 30170463, 30370307, and 30400239).}

Received April 26, 2005

Accepted September 1, 2005

\begin{abstract}
Curcumin, a major yellow pigment and active component of turmeric, has multiple anti-cancer properties. However, its molecular targets and mechanisms of action on human colon adenocarcinoma cells are unknown. In the present study, we examined the effects of curcumin on the proliferation of human colon adenocarcinoma HT-29 cells by the 3-[4,5-dimethylthiazol-2-yl]-2,5-diphenyltetrazolium bromide method and confirmed the curcumin-induced apoptosis by morphology and DNA ladder formation. At the same time, p53, phospho-p53 (Ser15), and other apoptosis-related proteins such as Bax, Bcl-2, Bcl$\mathrm{x}_{\mathrm{L}}$, pro-caspase- 3 , and pro-caspase- 9 were determined by Western blot analysis. The colon adenocarcinoma cells were treated with curcumin $(0-75 \mu \mathrm{M})$ for $0-24 \mathrm{~h}$. We observed that p53 was highly expressed in HT-29 cells and curcumin could up-regulate the serine phosphorylation of p53 in a time- and concentration-dependent manner. An increase in expression of the pro-apoptotic factor Bax and a decrease in expression of the anti-apoptotic factor Bcl-2 were also observed in a time-dependent manner after exposure of $50 \mu \mathrm{M}$ curcumin, while the expression of the anti-apoptotic factor Bcl- $\mathrm{x}_{\mathrm{L}}$ was unchanged. Curcumin could also down-regulate the expression of pro-caspase- 3 and pro-caspase- 9 in a time-dependent manner. These data suggest a possible underlying molecular mechanism whereby curcumin could induce the apoptosis signaling pathway in human HT29 colon adenocarcinoma cells by $\mathrm{p} 53$ activation and by the regulation of apoptosis-related proteins. This property of curcumin suggests that it could have a possible therapeutic potential in colon adenocarcinoma patients.
\end{abstract}

\section{Introduction}

Curcumin is the major yellow pigment in turmeric which is derived from the herb Curcuma longa Linn (1). Consumption of turmeric or curcumin has been associated with many beneficial effects on human health and
Key words

- Curcumin

- Apoptosis

- HT-29 cells

- p53

- Phosphorylation

- DNA ladder is currently receiving attention from cancer investigators for its chemopreventive properties against human malignancies. Recent studies have demonstrated that curcumin can be used for cancer prevention for its antiinflammatory, anti-oxidant, anti-cancer, antipsoriatic, and anti-atherogenic properties 
$(2,3)$. In vivo, curcumin suppresses carcinogenesis of the skin (4), the forestomach (5), the colon (6), the breast (7), and the liver (8) in mice, and in vitro, it has been shown to inhibit the growth of a wide variety of tumor cell lines (9). Although the mechanisms of the anti-cancer action of curcumin are not fully understood, in recent years, curcumininduced apoptosis by targeting mitochondria, affecting p53-related signaling or blocking NF- $\kappa \mathrm{B}$ activation, has emerged as the major anti-cancer mechanism (10).

The p53 protein has emerged as a key tumor suppressor protein by playing a central role in cellular stress response pathways. Through these pathways, one of its roles is to survey cellular stress and to induce apoptosis. p53 can promote apoptosis by several mechanisms (11). The Bcl-2 family has been shown to be a p53 target. Bax, the pro-apoptotic member, is up-regulated in a number of systems during p53-mediated apoptosis (12). On the other hand, down-regulation of Bcl-2, the antiapoptotic member, has also been demonstrated during apoptosis (12). Recent studies have proposed that the alteration of the $\mathrm{Bcl}-\mathrm{x}_{\mathrm{L}}$ (a pro-proliferative member of the Bcl-2 family) and Bax ratio is one of the important factors which decide the fate of a cell (13). However, the mechanism of curcumin-induced apoptosis involved in the regulation of the balance between these pro- and anti-apoptotic proteins is not fully clear.

Colon cancer is a serious health problem in most developed countries and is one of the leading causes of cancer mortality throughout the world (14). To date, chemoprevention is a major strategy since other therapies have not been effective in controlling either the high incidence or low survival rate of colon cancer (15). The anti-cancer properties of curcumin on colon cancer have been demonstrated in vivo $(6,16)$ and, in vitro, curcumin has been shown to inhibit the growth of human colon cancer cells independent of cyclooxygenase- 2 (COX-2) expression $(17,18)$. In order to extend the observations on the potential inhibi- tion of human colon adenocarcinoma cells by curcumin, in the present study we evaluated the effect of curcumin on HT-29 cells in vitro, and investigated the possible underlying molecular mechanism. The study showed that curcumin can induce the apoptosis signaling pathway in human HT-29 colon adenocarcinoma cells through p53 activation and the regulation of apoptosis-related proteins.

\section{Material and Methods}

\section{Antibodies}

Mouse anti-p53 monoclonal antibody and rabbit anti-phospho-p53 (Ser15) polyclonal antibodies were purchased from Calbiochem (Darmstadt, Germany). Rabbit anti-Bax, Bcl$\mathrm{x}_{\mathrm{L}}, \mathrm{Bcl}-2$, pro-caspase-3, and pro-caspase-9 were purchased from Santa Cruz Biotechnology (Santa Cruz, CA, USA). Mouse antiactin monoclonal antibody was purchased from Sigma Chemical Co. (St. Louis, MO, USA). Anti-rabbit IgG and anti-mouse IgG antibodies were purchased from Santa Cruz Biotechnology.

\section{Cell culture and curcumin treatment}

The human HT-29 colon adenocarcinoma cell line was obtained from the Institute of Biochemistry and Cell Biology, Chinese Academy of Sciences. The cells were maintained in Dulbecco's modified Eagle's medium (Life Technologies, Inc., Grand Island, NY, USA) supplemented with 10\% (v/ v) heat-inactivated fetal bovine serum, 100 $\mathrm{U} / \mathrm{mL}$ penicillin, and $0.1 \mathrm{mg} / \mathrm{mL}$ streptomycin in a humidified atmosphere of $95 \%$ air and $5 \% \mathrm{CO}_{2}$ at $37^{\circ} \mathrm{C}$. Curcumin (Sigma) was dissolved in DMSO at a concentration of 5 $\mathrm{mM}$ and was stored in a dark-colored bottle at $-20^{\circ} \mathrm{C}$ as a stock solution. The stock was diluted to the required concentration with serum-free medium immediately before use. Before treatment with curcumin, the medium was removed when cells were about 
$80 \%$ confluent, the cells were starved overnight in serum-free medium and then exposed to curcumin at different concentrations $(0-75 \mu \mathrm{M})$ and for different periods of time (0-72 h). Cells grown in medium containing an equivalent amount of DMSO without curcumin served as control.

\section{Cell viability assay}

Cell viability was assessed by the 3-[4,5dimethylthiazol-2-yl]-2,5-diphenyltetrazolium bromide (MTT, Sigma) method. Briefly, cells were plated onto a 96-well plate at a density of $5 \times 10^{3}$ cells/well in $200 \mu \mathrm{L}$ of medium. After $24 \mathrm{~h}$ they were treated with a series of curcumin concentrations $(0-75 \mu \mathrm{M})$ for $12,24,36$, 48, and $72 \mathrm{~h}$. After treatment, medium containing curcumin was carefully removed, and $100 \mu \mathrm{L}$ MTT solution $(0.25 \mathrm{mg} / \mathrm{mL}$ in PBS $)$ was added to each well. After $4 \mathrm{~h}$ of incubation at $37^{\circ} \mathrm{C}$, MTT was discarded and $200 \mu \mathrm{L}$ of extraction buffer (90\% DMSO, $10 \% 0.1 \mathrm{~mol} /$ $\mathrm{L}$ glycine- $\mathrm{NaOH}, \mathrm{pH} 10.0$ ) was added to each well, followed by shaking for $30 \mathrm{~min}$. Absorbance (A) at $570 \mathrm{~nm}$ was measured with an ELISA plate reader, with the extraction buffer used as a blank. Percent cell viability was calculated as follows: A of the experimental group/A of the control group x $100 \%$.

\section{Cell morphology studies}

After treatment with $50 \mu \mathrm{M}$ curcumin for $24 \mathrm{~h}$, the cells, cultured on glass coverslips, were washed three times with PBS, fixed with 3\% paraformaldehyde for $10 \mathrm{~min}$ at room temperature, and then washed in PBS again, and the morphological changes were observed. Some cells were incubated with $10 \mu \mathrm{g} / \mathrm{mL}$ Hoechst 33258 (Calbiochem, San Diego, CA, USA) for $10 \mathrm{~min}$. In addition, when the cells had been treated for the indicated time, both adherent cells and floating cells were centrifuged and the pellet was resuspended in $2 \mu \mathrm{L}$ acridine orange and ethidium bromide $(\mathrm{AO} /$ $\mathrm{EB}, \mathrm{AO} 100 \mu \mathrm{g} / \mathrm{mL}$ and $\mathrm{EB} 100 \mu \mathrm{g} / \mathrm{mL}$ in
PBS). Cell morphology was then observed by fluorescence microscopy (Leica DM IRB, Wetzlar, Germany).

\section{DNA fragmentation assay}

Briefly, cells $\left(2 \times 10^{6}\right)$ were harvested and lysed in cold buffer containing $10 \mathrm{mM}$ Tris-HCl, $\mathrm{pH}$ 8.0, $150 \mathrm{mM} \mathrm{NaCl}, 2 \mathrm{mM}$ $\mathrm{MgCl}_{2}, 1 \mathrm{mM}$ dithiothreitol (DTT), and $0.5 \%$ $\mathrm{NP}-40$ on ice for $40 \mathrm{~min}$. Lysates were centrifuged and the pellets were resuspended in cold buffer containing $10 \mathrm{mM}$ Tris- $\mathrm{HCl}$, $\mathrm{pH} 8.0,350 \mathrm{mM} \mathrm{NaCl}, 1 \mathrm{mM} \mathrm{MgCl} 2$, and $1 \mathrm{mM}$ DTT on ice for $20 \mathrm{~min}$. Lysates were then extracted once with a phenol: chloroform:isoamyl alcohol mixture (25: 24:1) and DNA was precipitated with 10 $\mathrm{mM} \mathrm{MgCl} 2$ and 2.5 volumes $100 \%$ ethanol overnight at $-20^{\circ} \mathrm{C}$. DNA was collected by centrifugation at $14,000 \mathrm{~g}$ for $20 \mathrm{~min}$, resuspended in TE buffer (10 mM Tris- $\mathrm{HCl}, \mathrm{pH}$ 8.0, $1 \mathrm{mM}$ EDTA) plus $0.1 \mathrm{mg} / \mathrm{mL}$ RNase A, and incubated at $37^{\circ} \mathrm{C}$ for $1 \mathrm{~h}$. Proteinase $\mathrm{K}(1$ $\mathrm{mg} / \mathrm{mL}$ ) was added and the mixture was incubated at $37^{\circ} \mathrm{C}$ for an additional hour. Fragmented DNA was then electrophoresed in $1.5 \%$ agarose gels containing $0.5 \mu \mathrm{g} / \mathrm{mL}$ EB.

\section{Western blot analysis}

After harvesting, the experimental cells were washed twice with PBS and lysed in lysis buffer (20 mM Tris-HCl, $100 \mathrm{mM} \mathrm{NaCl}, 20$ $\mathrm{mM} \mathrm{KCl}, 1.5 \mathrm{mM} \mathrm{MgCl} 2,50 \mathrm{mM} ß$-GPA, 10 $\mathrm{mM} \mathrm{NaF}, 0.5 \%$ NP-40, plus proteinase and phosphatase inhibitors) for $10 \mathrm{~min}$ and centrifuged at $12,000 \mathrm{~g}$ for $10 \mathrm{~min}$ at $4^{\circ} \mathrm{C}$. Total protein, as determined by the Bio-Rad protein assay, was mixed with $4 \mathrm{X}$ loading buffer, and pre-heated at $95^{\circ} \mathrm{C}$ for $10 \mathrm{~min}$. The samples were then loaded on SDS-polyacrylamide gel and the proteins were transferred to a PVDF membrane for $1.5 \mathrm{~h}$ using a semi-dry transfer system (Bio-Rad, Hercules, CA, USA). The membrane was blocked in $0.25 \%$ gelatin for $1.5 \mathrm{~h}$ at room temperature and then incubated 
for $1.5 \mathrm{~h}$ with primary antibody. After hybridization with the primary antibody, the membrane was washed with Tris-buffered saline containing Tween-20 three times, then incubated with HRP-labeled secondary antibody for $1 \mathrm{~h}$ at room temperature and washed with Tris-buffered saline containing Tween-20 three times. Final detection was performed with ECL enhanced chemiluminescence Western blotting reagents (Amersham, Pharmacia Biotech, Piscataway, NJ, USA). The blot was then stripped in buffer (62.5 mM Tris-HCl, $\mathrm{pH}$ 6.8, 2\% SDS, $200 \mathrm{mM}$ 2-mercaptoethanol) at $50^{\circ} \mathrm{C}$ for $30 \mathrm{~min}$. After extensive washing, the same blot was used to probe for the next protein, beginning from the blocking step.

\section{Results}

Effect of curcumin on the growth of HT-29 cells

We examined the effects of different concentration of curcumin on the viability of
Figure 1. Effect of curcumin on HT-29 cell viability. Cell viability was determined by the 3-[4,5dimethylthiazol-2-yl]-2,5-diphenyltetrazolium bromide assay. Data are reported as the means \pm SD of three separate experiments.

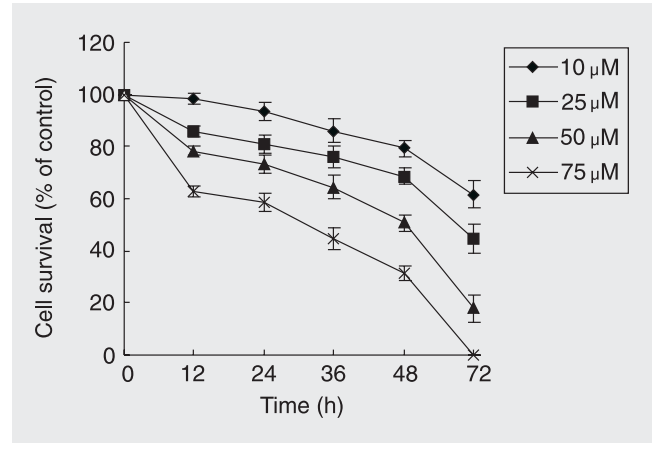

Figure 2. Curcumin induces DNA fragmentation in HT-29 cells. A, Cells were treated with $50 \mu \mathrm{M}$ curcumin and the control was treated with medium containing an equivalent amount of DMSO without curcumin. At the indicated times, the cells were harvested and lysed. DNA fragmentation was examined by agarose gel electrophoresis. $B$, Cells were incubated in medium containing curcumin at the indicated concentrations for $48 \mathrm{~h}$. The cells were harvested and lysed. DNA fragmentation was examined by agarose gel electrophoresis. (M: 1 kb DNA marker).

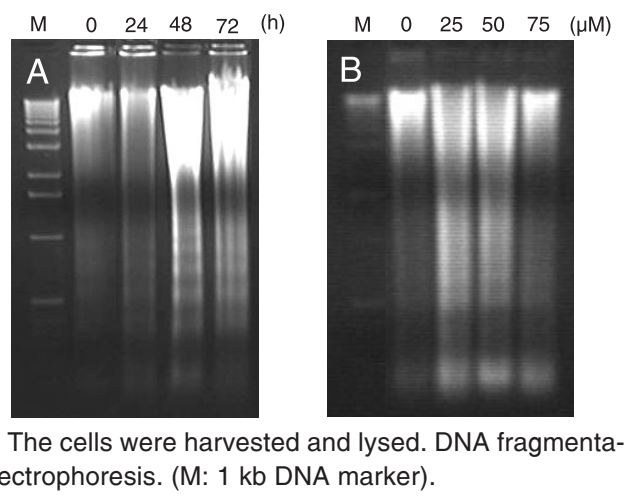

HT-29 cells for $12,24,36,48$, and 72 h by the MTT method (Figure 1). Curcumin inhibited growth in a concentration- and timedependent manner. At the concentration used here $(50$ and $75 \mu \mathrm{M})$, a significant loss of viability was detectable during the $48 \mathrm{~h}$ of treatment. The cell growth-inhibiting rate was about $80 \%$ at $50 \mu \mathrm{M}$ curcumin concentration after $72 \mathrm{~h}$ of treatment. Furthermore, DNA fragmentation, a hallmark event in cell apoptosis, was also detected in a concentration- and time-dependent manner in HT-29 cells (Figure 2A,B). The results showed a typical ladder pattern of internucleosomal fragmentation in HT-29 cells treated with 25 and $50 \mu \mathrm{M}$ curcumin for 48 and $72 \mathrm{~h}$.

\section{Effect of curcumin on cell morphology of HT-29 cells}

To determine curcumin-induced apoptosis of HT-29 cells, we first examined the changes in cell morphology after exposure to curcumin. Twenty-four hours after exposure to $50 \mu \mathrm{M}$ curcumin, HT-29 cells began to show cell shrinkage, rounding and fragmentation, thus taking on the typical appearance of apoptotic cells when compared to untreated cells (Figure 3A). We also analyzed changes in cell morphology by Hoechst 33258 (Figure 3B) and AO/EB (Figure 3C) staining. The curcumin-treated cells also exhibited morphological changes indicative of apoptosis, including chromatin condensation and nuclear fragmentation.

\section{Effect of curcumin on the serine} phosphorylation of p53.

p53 has been shown to be involved in apoptosis induced by a broad range of agents. In order to understand the exact mechanism of curcumin-induced apoptosis in HT-29 cells, we first examined the activation of p53 in the presence of $50 \mu \mathrm{M}$ curcumin for different periods of time or at different curcumin concentrations for $6 \mathrm{~h}$. Results showed 
very little or no change of total p53 expression for different exposure times or at different concentrations for $6 \mathrm{~h}$ (Figure 4A, B). However, a notable change was observed in p53 phosphorylation. Upon treatment with $50 \mu \mathrm{M}$ curcumin, the serine phosphorylation level of p53 started to increase as early as after $1 \mathrm{~h}$, and reached a high level at $6 \mathrm{~h}$ (Figure 4A). The serine phosphorylation level of p53 also started to increase in a concentration-dependent manner. Upon treatment with $75 \mu \mathrm{M}$ curcumin, the serine phosphorylation level of p53 reached a maximum level after
$6 \mathrm{~h}$ as compared to other curcumin concentrations (Figure 4B).

\section{Effect of curcumin on the expression of} apoptosis-related proteins

To further understand the mechanism of curcumin-induced apoptosis in HT-29 cells, we also examined the expression of apoptosis-related proteins. $\mathrm{Bcl}-\mathrm{x}_{\mathrm{L}}$ levels were moderately high in HT-29 cells and remained almost unchanged after curcumin treatment, but Bcl-2 levels decreased after $4 \mathrm{~h}$. On the
A

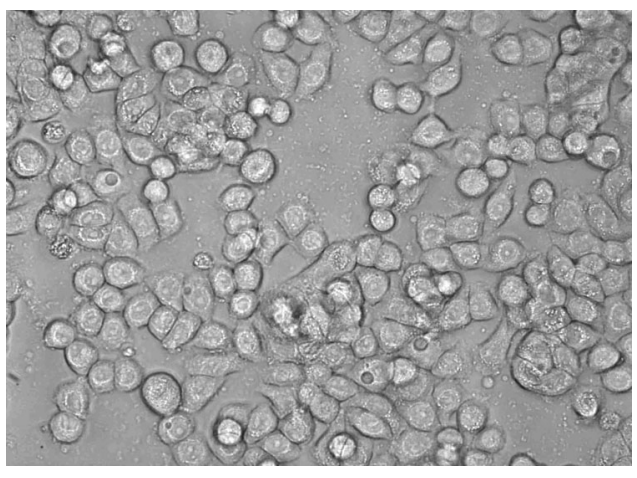

B

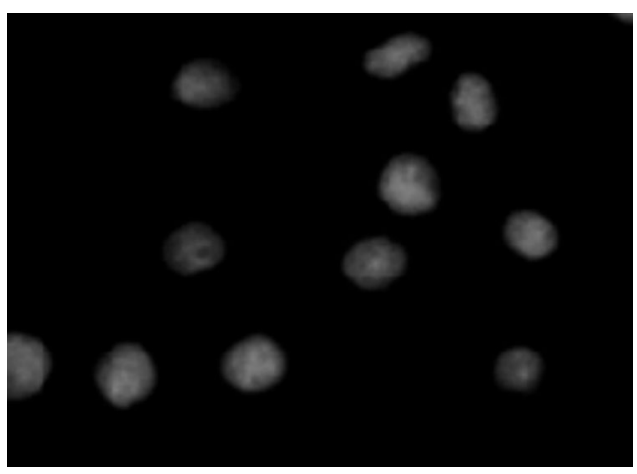

C

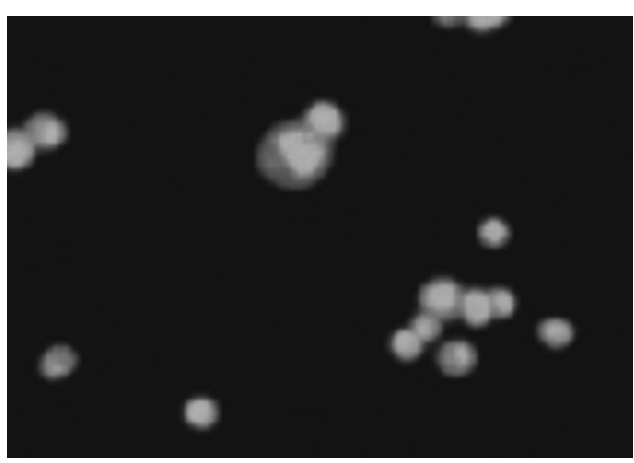

$50 \mu \mathrm{M}$ curcumin
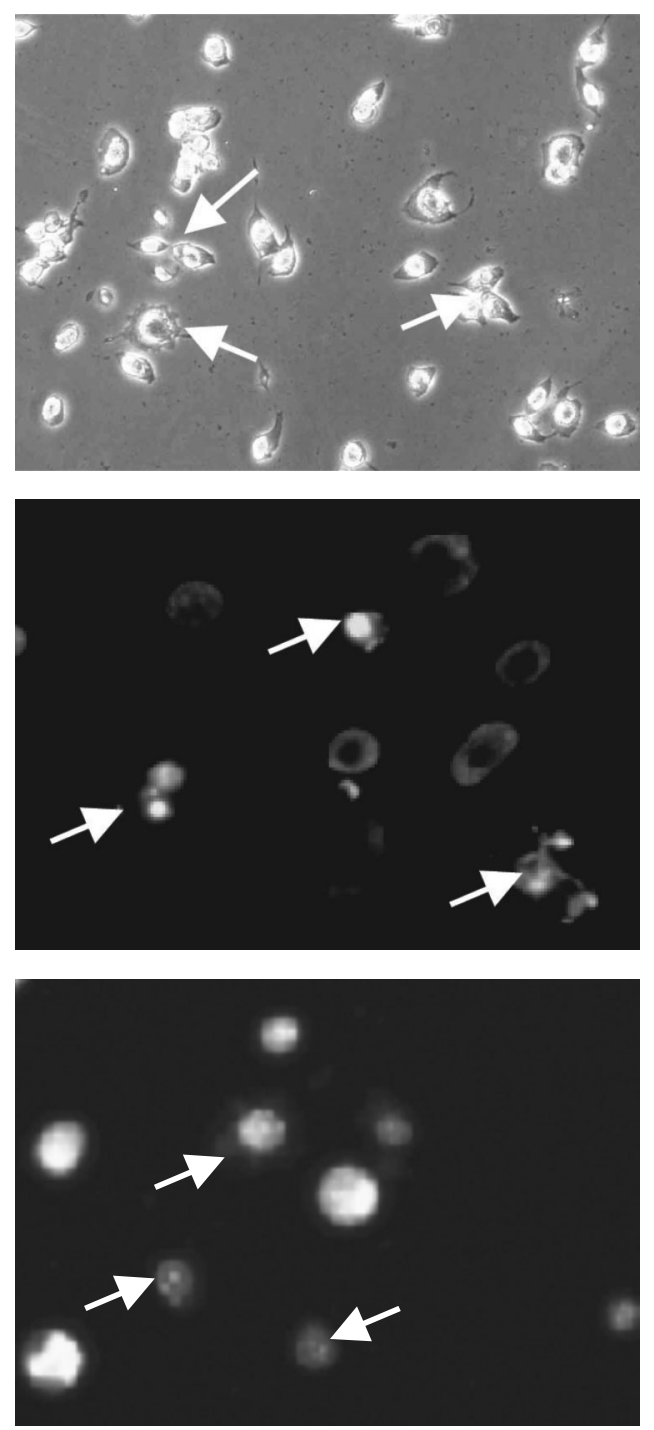

Figure 3. Morphological changes of HT-29 cells after exposure to curcumin. HT-29 cells were treated with DMSO (control) or $50 \mu \mathrm{M}$ curcumin for $24 \mathrm{~h}$. $A$, The images were captured by phase contrast microscopy (Leica DM IRB). Original magnification, 200X. $B$, Cells were fixed and stained with Hoechst 33258, and the images were captured by fluorescence microscopy (Leica DM IRB). Original magnification, 400X. C, Cells were harvested and stained with $\mathrm{AO} /$ $E B$, and the images were captured by fluorescence microscopy (Leica DM IRB). Original magnification, 400X. The arrows indicate cells undergoing apoptosis. 
other hand, the Bax levels increased significantly and remained higher after $4 \mathrm{~h}$ (Figure $5 \mathrm{~A})$. The levels of pro-caspase- 3 and procaspase-9 zymogen in HT-29 cells treated with $50 \mu \mathrm{M}$ curcumin were low and decreased in a time-dependent manner. Simultaneously, we observed a clear reduction of pro-caspase- 9 zymogen expression after $6 \mathrm{~h}$ of curcumin treatment (Figure 5B).

\section{Discussion}

Curcumin [1,7-bis(4-hydroxy-3-methoxyphenyl)-1,6-heptadiene-3,5-dione] is a hydrophobic molecule that passes easily through the plasma membrane into the cytosol (19). This phenolic substance inhibits tumor initiation induced by various carcinogens and has also been shown to inhibit the growth of many human cancer cell lines in vitro (9). A number of mechanisms of cell proliferation inhibition and apoptosis induction by curcumin have been demonstrated. The present results and other literature reports $(17,18)$ show that curcumin strongly reduces the viability of HT-29 colon adenocarcinoma cells by the induction of apoptosis. However, the signaling pathways governing apoptosis in mammalian cells are complex and the pro- and anti-apoptotic variations regulating cell survival change according to cell type (20). The cellular and molecular mechanisms underlying curcumininduced apoptosis in HT-29 cells have not been well defined. Therefore, it is interesting to study the mechanism of action of curcumin on HT-29 cells.

In agreement with a previous study (18),
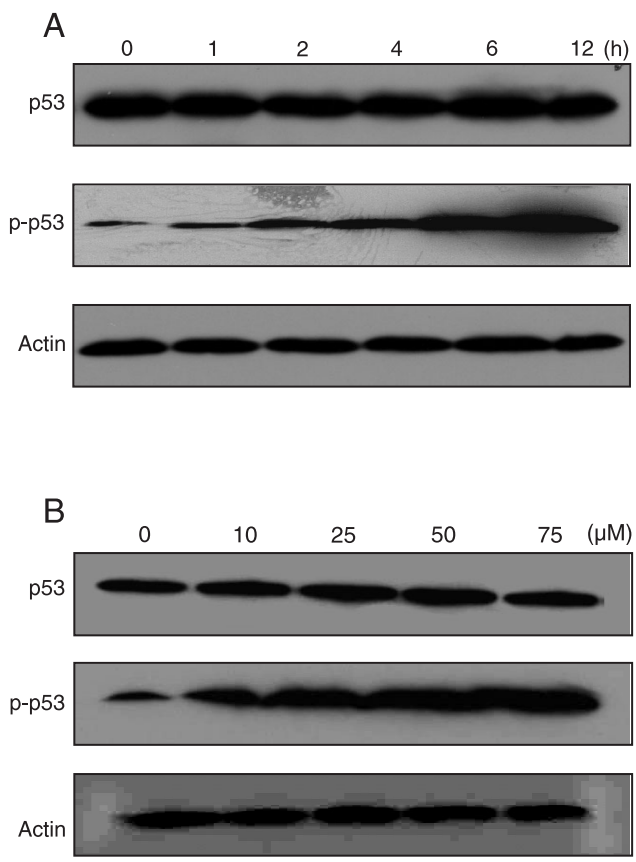

Figure 4. Enhanced serine phosphorylation of p53 in HT-29 cells by treatment with curcumin. $A$, Cells were incubated in serumfree medium overnight and then further incubated for $0,1,2,4$, 6 , and $12 \mathrm{~h}$ in the presence of $50 \mu \mathrm{M}$ curcumin. B, Cells were incubated in serum-free medium overnight and then further incubated for $6 \mathrm{~h}$ in the presence of $0,10,25,50$, and $75 \mu \mathrm{M}$ curcumin, respectively. Equal amounts of cell lysates were resolved by SDSPAGE and analyzed by Western blot using specific antibodies. The blots were re-probed with anti-actin antibody to confirm equal protein loading.
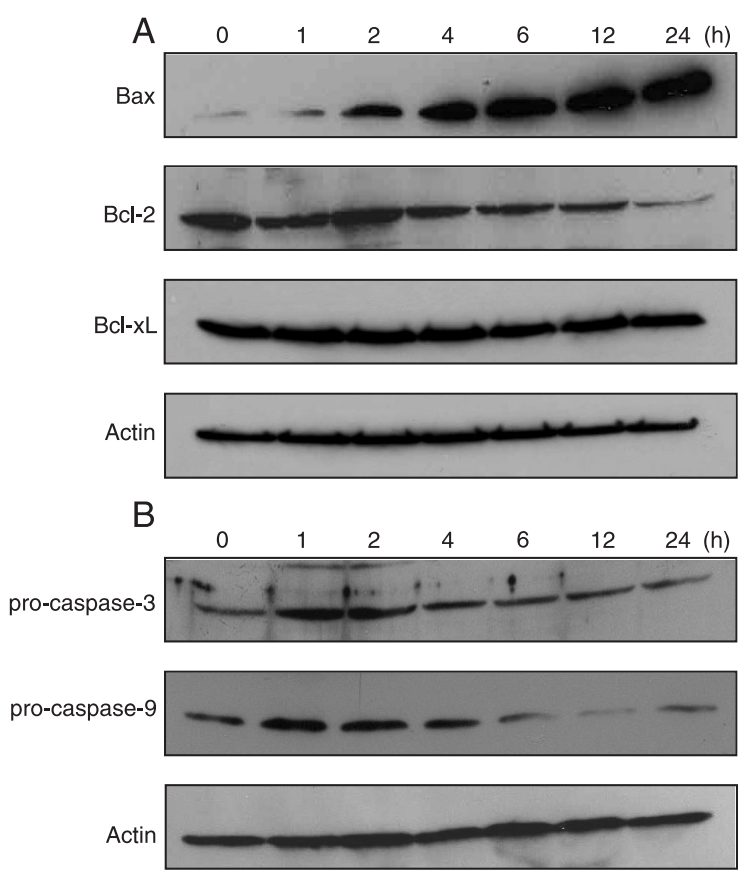

Figure 5. Expression of the apoptosis-related proteins Bax, Bcl-2, $\mathrm{Bcl}-\mathrm{x}_{\mathrm{L}}$, pro-caspase- 3 , and pro-caspase- 9 in HT-29 cells by treatment with curcumin. $A$, Cells were incubated in serum-free medium overnight and further incubated for $0,1,2,4,6,12$, and $24 \mathrm{~h}$ in the presence of $50 \mu \mathrm{M}$ curcumin. $B$, Cells were incubated in serum-free medium overnight and then further incubated for $6 \mathrm{~h}$ in the presence of $0,10,25,50$, and $75 \mu \mathrm{M}$ curcumin, respectively. Equal amounts of cell lysates were resolved by SDS-PAGE and analyzed by Western blot using specific antibodies. The blots were re-probed with antiactin antibody to confirm equal protein loading. 
the present investigation showed that curcumin inhibited the growth of HT-29 colon adenocarcinoma cells in a concentrationand time-dependent manner. In our study, however, we observed that a cell growth inhibitory rate of about $80 \%$ occurred at the curcumin concentration of $50 \mu \mathrm{M}$ after $72 \mathrm{~h}$ of treatment. In contrast to our results, in a previous report the same cell growth inhibitory effect of curcumin was observed at about $75 \mu \mathrm{M}$ after $72 \mathrm{~h}$ of treatment (18). We also observed a typical ladder pattern of internucleosomal fragmentation through DNA fragmentation in HT-29 cells treated with $50 \mu \mathrm{M}$ curcumin for $48 \mathrm{~h}$. Similar effects of curcumin in inhibiting cell growth have been previously reported for other colon cancer lines $(21,22)$.

In a study of the mechanism of action of curcumin on HT-29 cells, Hanif et al. (17) reported that curcumin inhibits the growth of human colon cancer cells independent of COX-2 expression. Goel et al. (18) also reported that curcumin markedly inhibited the mRNA and protein expression of COX2 , but not of COX-1. In the present study, we propose another possible underlying molecular mechanism of curcumin-induced HT29 cell apoptosis via the activation of p53 and the regulation of apoptosis-related proteins. Despite its central role in cell apoptosis, the mechanism of p53-mediated apoptosis after cellular stress remains unclear. Current evidence indicates that the mode of action of p53-mediated apoptosis involves transactivation of target genes and direct signaling events that are transcription independent (23). It has been proposed that p53 may induce two sets of genes upon stress signals. One set, such as p21/waf-1 and GADD45, mainly functions in cell growth control, and the other, such as Bax and Bcl2 , acts on apoptosis (24).

In the present study, we observed that p53 was highly expressed in HT-29 cells, but the total p53 protein was almost unchanged. This was in agreement with previ- ous reports $(25,26)$. However, we found that the serine phosphorylation level of p53 was enhanced prominently when HT-29 cells were treated by curcumin. A recent study implicated that curcumin could impair p53 function required for serine phosphorylation of p53 in colon cancer cells (27). The activation of p53 by curcumin would affect the expression of its downstream effectors, such as the Bcl-2 family proteins. This implies a possible underlying molecular mechanism of curcumin action on HT-29 cells.

It is well recognized that the Bcl-2 family proteins are central regulators of apoptosis and the Bcl-2 family members act like checkpoints through which survival and death signals pass before they determine the fate of the cell (20). In our study, the high serine phosphorylation level of p53 was shown to be capable of both down-regulating the antiapoptotic factor, $\mathrm{Bcl}-2$ and up-regulating the pro-apoptotic factor Bax, thereby decreasing the $\mathrm{Bcl}-2 / \mathrm{Bax}$ ratio and disposing to apoptosis. Interestingly, curcumin induced apoptosis with an increased serine phosphorylation level of $\mathrm{p} 53$ which transactivates Bax expression. But in these cells, Bcl- $\mathrm{x}_{\mathrm{L}}$ levels remained almost unchanged, thereby shifting the $\mathrm{Bcl}-\mathrm{x}_{\mathrm{L}} / \mathrm{Bax}$ ratio towards apoptosis. The activation of the p53-mediated apoptotic signaling pathway may play an important role in apoptosis by modulating the $\mathrm{Bcl}-2 / \mathrm{Bax}$ or $\mathrm{Bcl}-\mathrm{x}_{\mathrm{L}} / \mathrm{Bax}$ ratio, as also reported for breast cancer cells (28).

p53-mediated transcriptionally activated pro-apoptotic proteins are usually classified into two groups including the death-receptor pathway and the mitochondrial apoptotic pathway. Caspases are the key proteins that modulate the apoptotic response and are represented by a family of cysteine proteases (29). Caspase-3 is a key executioner of apoptosis, which is activated by an initiator caspase such as caspase-9. These activated caspases cleave many cellular substrates, ultimately leading to cell death (29). We found that curcumin could down-regulate 
pro-caspase- 9 and pro-caspase- 3 expression in a time-dependent manner on the HT-29 cells. Our results agree with data reported for other cancer cell lines $(30,31)$.

Taken together, our results show that curcumin induces apoptosis in HT-29 colon adenocarcinoma cells by up-regulating the serine phosphorylation level of p53 and the level of Bax, while down-regulating the levels of Bcl-2, pro-caspase-3, and pro-caspase-9. These findings suggest a mechanism of curcumin action on HT-29 cells and should further establish its use as a valid chemopreventive and chemotherapeutic agent in colon cancer.

\section{References}

1. Ammon HPT \& Wahl MA (1991). Pharmacology of Curcuma longa. Planta Medica, 57: 1-7.

2. Lin JK \& Lin-Shiau SY (2001). Mechanisms of cancer chemoprevention by curcumin. Proceedings of the National Science Council, Republic of China. Part B, Life Sciences, 25: 59-66.

3. Joe B, Vijaykumar M \& Lokesh BR (2004). Biological properties of curcumin cellular and molecular mechanisms of action. Critical Reviews in Food Science and Nutrition, 44: 97-111.

4. Limtrakul P, Lipigorngoson S, Namwong $O$ et al. (1997). Inhibitory effect of dietary curcumin on skin carcinogenesis in mice. Cancer Letters, 116: 197-203.

5. Singh SV, Hu X, Srivastava SK et al. (1998). Mechanism of inhibition of benzo [a] pyrene-induced forestomach cancer in mice by dietary curcumin. Carcinogenesis, 19: 1357-1360.

6. Kawamori T, Lubet R, Steele VE et al. (1999). Chemopreventive effect of curcumin, a naturally occurring anti-inflammatory agent, during the promotion/progression stages of colon cancer. Cancer Reseach, 59: 597-601.

7. Inano H, Onoda M, Inafuku $\mathrm{N}$ et al. (1999). Chemoprevention by curcumin during the promotion stage of tumorigenesis of mammary gland in rats irradiated with gamma rays. Carcinogenesis, 20: 10111018.

8. Chuang SE, Kuo ML, Hsu CH et al. (2000). Curcumin-containing diet inhibits diethylnitrosamine-induced murine hepatocarcinogenesis. Carcinogenesis, 21: 331-335.

9. Aggarwal BB, Kumar A \& Bharti AC (2003). Anticancer potential of curcumin: preclinical and clinical studies. Anticancer Reseach, 23: 363-398.

10. Leu TH \& Maa MC (2002). The molecular mechanisms for the antitumorigenic effect of curcumin. Current Medicinal Chemistry, 2: 357-370.

11. Hofseth LJ, Hussain SP \& Harris CC (2004). p53: 25 years after its discovery. Trends in Pharmacological Sciences, 25: 177-181.

12. Martin DA \& Elkon KB (2004). Mechanisms of apoptosis. Rheumatic Diseases Clinics of North America, 30: 441-454.

13. Gonzalez de Aguilar JL, Gordon JW, Rene F et al. (2000). Alteration of the $\mathrm{Bcl}-\mathrm{x} / \mathrm{Bax}$ ratio in a transgenic mouse model of amyotrophic lateral sclerosis: evidence for the implication of the p53 signaling pathway. Neurobiology of Disease, 7: 406-415.

14. Labianca R, Beretta G, Gatta G et al. (2004). Colon cancer. Critical Reviews in Oncology/Hematology, 51: 145-170.

15. Gustin DM \& Brenner DE (2002). Chemoprevention of colon cancer: current status and future prospects. Cancer and Metastasis Reviews, 21: 323-348

16. Huang MT, Wang ZY, Georgiadis CA et al. (1992). Inhibitory effects of curcumin on tumor initiation by benzo [a] pyrene and 7,12-dimethylbenz [a] anthracene. Carcinogenesis, 13: 2183-2186.
17. Hanif R, Qiao L, Shiff SJ et al. (1997). Curcumin, a natural plant phenolic food additive, inhibits cell proliferation and induces cell cycle changes in colon adenocarcinoma cell lines by a prostaglandin-independent pathway. Journal of Laboratory and Clinical Medicine, 130: 576-584.

18. Goel A, Boland CR \& Chauhan DP (2001). Specific inhibition of cyclooxygenase-2 (COX-2) expression by dietary curcumin in HT29 human colon cancer cells. Cancer Letters, 172: 111-118.

19. Oetari S, Sudibyo M, Commandeur JN et al. (1996). Effects of curcumin on cytochrome P450 and glutathione S-transferase activities in rat liver. Biochemical Pharmacology, 51: 39-45.

20. Cory S \& Adams JM (2002). The Bcl-2 family: regulators of the cellular life-or-death switch. Nature Reviews. Cancer, 2: 647-656.

21. Collett GP \& Campbell FC (2004). Curcumin induces c-jun N-terminal kinase-dependent apoptosis in HCT116 human colon cancer cells. Carcinogenesis, 25: 2183-2189.

22. Rashmi R, Kumar S \& Karunagaran D (2004). Ectopic expression of $\mathrm{Bcl}-\mathrm{X}_{\mathrm{L}}$ or Ku70 protects human colon cancer cells (SW480) against curcumin-induced apoptosis while their down-regulation potentiates it. Carcinogenesis, 25: 1867-1877.

23. Haupt S, Berger M, Goldberg Z et al. (2003). Apoptosis - the p53 network. Journal of Cell Science, 116: 4077-4085.

24. Agarwal ML, Taylor WR, Chernov MV et al. (1998). The p53 network. Journal of Biological Chemistry, 273: 1-4.

25. Rodrigues NR, Rowan A, Smith ME et al. (1990). p53 mutations in colorectal cancer. Proceedings of the National Academy of Sciences, USA, 87: 7555-7559.

26. Van Erk MJ, Teuling E, Staal YC et al. (2004). Time- and dosedependent effects of curcumin on gene expression in human colon cancer cells. Journal of Carcinogenesis, 3: 8-24.

27. Moos PJ, Edes K, Mullally JE et al. (2004). Curcumin impairs tumor suppressor p53 function in colon cancer cells. Carcinogenesis, 25: 1611-1617.

28. Choudhuri T, Pal S, Agwarwal ML et al. (2002). Curcumin induces apoptosis in human breast cancer cells through p53-dependent Bax induction. FEBS Letters, 512: 334-340.

29. Earnshaw WC, Martins LM \& Kaufmann SH (1999). Mammalian caspases: Structure, activation, substrates, and functions during apoptosis. Annual Review of Biochemistry, 68: 383-424.

30. Khar A \& Ali AM (1999). Antitumor activity of curcumin is mediated through the induction of apoptosis in AK-5 tumor cells. FEBS Letters, 445: 165-168.

31. Bush JA, Cheung Jr KJ \& Li G (2001). Curcumin induces apoptosis in human melanoma cells through a Fas receptor/caspase-8 pathway independent of p53. Experimental Cell Research, 271: 305314. 